\title{
Off-rift volcanism in rift zones determined by crustal unloading
}

\author{
Francesco Maccaferri ${ }^{1,2 \star}$, Eleonora Rivalta ${ }^{1,2}$, Derek Keir $^{3}$ and Valerio Acocella ${ }^{4}$
}

\begin{abstract}
When continents are stretched over a long period of time, deep elongated rift valleys form at Earth's surface and zones of ponded magma, centred beneath the rift, form at the crust-mantle boundary ${ }^{1,2}$. Ascending magma sometimes erupts within the rift valley ${ }^{3,4}$ or, counterintuitively, at volcanic fields away from the rift valley that are offset by tens of kilometres from the source of magma at depth ${ }^{5-8}$. The controls on the distribution of this off-rift volcanism are unclear. Here we use a numerical model of magmatic dyke propagation during rifting to investigate why some dykes reach the surface outside the rift valley, whereas others are confined to the valley. We find that the location of magmatism is governed by the competition between tectonic stretching and gravitational unloading pressure, caused by crustal thinning and faulting along the rift borders. When gravitational unloading dominates over tectonic stretching forces, dykes ascending from the ponded magma are steered towards the rift sides, eventually causing off-rift eruptions. Our model also predicts the formation of stacked magma sills in the lower crust above the magma-ponding zone, as well as the along-rift propagation of shallow dykes during rifting events, consistent with observations of magmatism and volcanism in rift zones globally. We conclude that rift topography-induced stress changes provide a fundamental control on the transfer of magma from depth to the surface.
\end{abstract}

Continental rifts are commonly flanked by magmatism during their early stages ${ }^{5,6}$. In the Miocene-Recent Main Ethiopian Rift (MER), for example, many Pliocene volcanoes lie outside the Miocene rift border faults ${ }^{9,10}$ (Fig. 1). As the cumulative extension has increased, magmatism has become focused within the rift axis $^{3}$. A similar pattern is observed during the evolution of the Red Sea Rift, where $\sim 25$-Myr-old rift-parallel dykes focus near the $\sim 30$-Myr-old rift margins and the youngest volcanoes focus along the ridge axis ${ }^{11}$. Even in far less magmatically active settings, such as the Baikal Rift (Siberia) or the Chaine des Puys (CdP) in the Cenozoic rift system of France, off-rift volcanism occurred after the onset of rifting ${ }^{7,8}$.

During rift initiation, the lithosphere thins by ductile stretching beneath a rift valley formed from normal faulting ${ }^{12}$. The upwelling asthenosphere melts by adiabatic decompression, with the greatest degree of partial melting beneath the most thinned rift valley ${ }^{1,2}$. Although most studies focus on in-rift magmatism ${ }^{3,4}$, a model is needed to explain how off-rift volcanoes are fed. Progressive rift spreading results in the oldest volcanoes being transported away from the rift axis. However, such a process does not explain off-rift volcanism, with volcanoes located outside the rift border faults. Previous models for off-rift volcanoes include low-angle detachments tapping the asthenosphere to the sides of highly asymmetric rifts ${ }^{13}$, or the flexural response at the base of the footwall of the active rift border faults ${ }^{5}$. These models are unsatisfactory, because geophysical evidence of highly asymmetric magmatic rifts and offset magmatic sources is lacking and any flexural response should induce horizontal compression at the top of the footwall of the rift border faults, preventing shallow dyke propagation.

Although magma at mantle depths ascends by porous flow, in the crust, dyking is the most viable mechanism of transport. We use numerical models to investigate the ascent of magma-filled dykes in the stress field induced in the elastic layers of the crust by tectonic extension and unloading due to a topographic depression ${ }^{14}$. Elastic shear stresses in the upper crust are expected to persist over millions of years; the effect of a weak lower crust is discussed below. With a two- dimensional numerical model ${ }^{15}$ we calculate the trajectories of ascending dykes from a magma ponding zone at the crust-mantle boundary or from a crustal reservoir (at depth $z_{\text {in }}$ ) with lateral extent equal to the half-width of the graben (Fig. 2). We model dykes as boundary-element cracks composed of $N$ contiguous and interacting dislocation elements propagating in a brittle elastic halfspace. The dyke opens under assigned normal and shear stress given by the internal overpressure and by the shear component of the tectonic plus unloading stresses, respectively. The overpressure within the dyke is the difference between the magma pressure and the confining stress: which is the superposition of the lithostatic pressure, the normal component of the topographic unloading and the tectonic stress (assumed as homogeneous horizontal stretching $\sigma_{\text {tec }}=5 \mathrm{MPa}$ ). The fluid pressure is given by a magma-static (linear) profile and accounts for magma compressibility, with a magma-rock density contrast of $80-300 \mathrm{~kg} \mathrm{~m}^{-3}$ (Supplementary Table 1). The dykes are nucleated perpendicular to the minimum compressive stress $\sigma_{3}$. Their trajectories are calculated by testing incremental elongations in different directions and selecting the one maximizing the elastic and gravitational energy release $\mathrm{e}^{15}$.

Our models suggest that dykes may reach the surface both within and outside the rift, depending on the competition between tectonic stretching and unloading pressure, and on the nucleation depth of the dykes. The unloading stress field is controlled by the graben width, $W$, and the effective depth, $D$, accounting for the total deficit of mass from the topographic depression and low-density sediments. When the unloading pressure $P_{0}=\rho g D$ ( $\rho$ is crustal density, $g$ acceleration due to gravity) dominates over the tectonic stretching $\left(K=\pi \sigma_{\text {tec }} /\left(2 P_{0}\right)<1\right.$, which translates into $D>\pi \sigma_{\text {tec }} /(2 \rho g) 250 \mathrm{~m}$ for $\rho=3,000 \mathrm{~kg} \mathrm{~m}^{-3}$; see Methods), $\sigma_{3}$ becomes vertical beneath the rift in a volume centred at a depth $z_{\mathrm{c}}=\rho g D W /\left(\pi \sigma_{\mathrm{tec}}\right)$ with upper and lower depths $z_{1}=(W / 2 K)\left(1-\left(1-K^{2}\right)^{1 / 2}\right)$ and $z_{2}=(W / 2 K)\left(1+\left(1-K^{2}\right)^{1 / 2}\right)$,

${ }^{1}$ GFZ German Centre for Geosciences, Section 2.1, Telegrafenberg, 14473 Potsdam, Germany, ${ }^{2}$ Institute of Geophysics, University of Hamburg, Bundesstr. 55, 20146, Hamburg, Germany, ${ }^{3}$ National Oceanography Centre Southampton, University of Southampton, Southampton, SO14 3ZH, UK, ${ }^{4}$ Dipartimento di Scienze, University of Roma Tre, L. S.L. Murialdo, 1, 00146, Roma, Italy. *e-mail: francesco.maccaferri@gfz-potsdam.de 
a

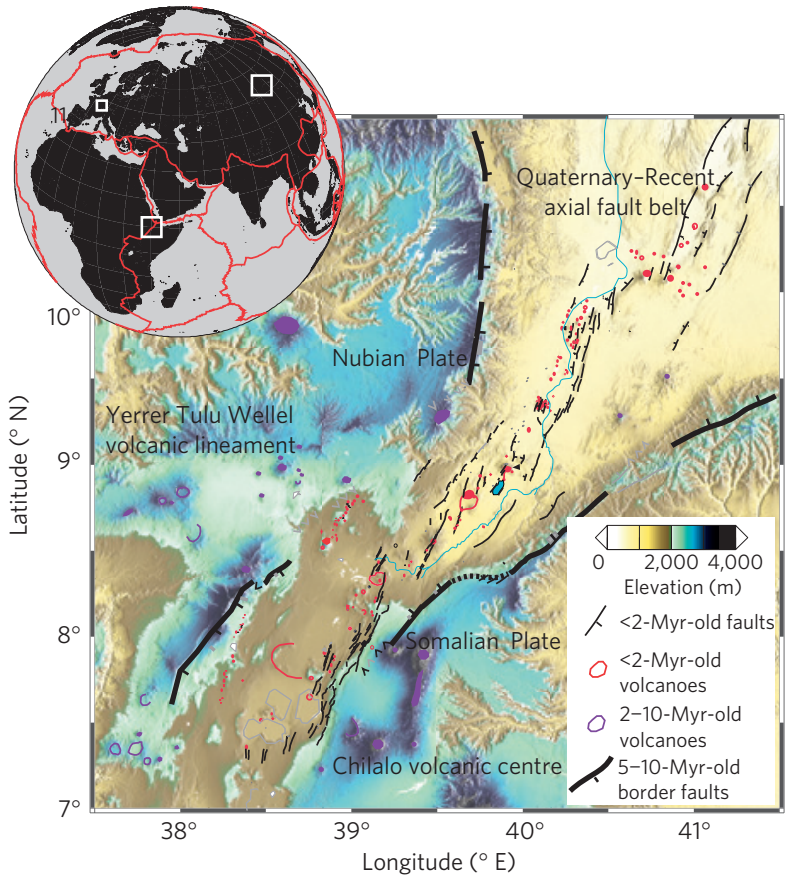

b

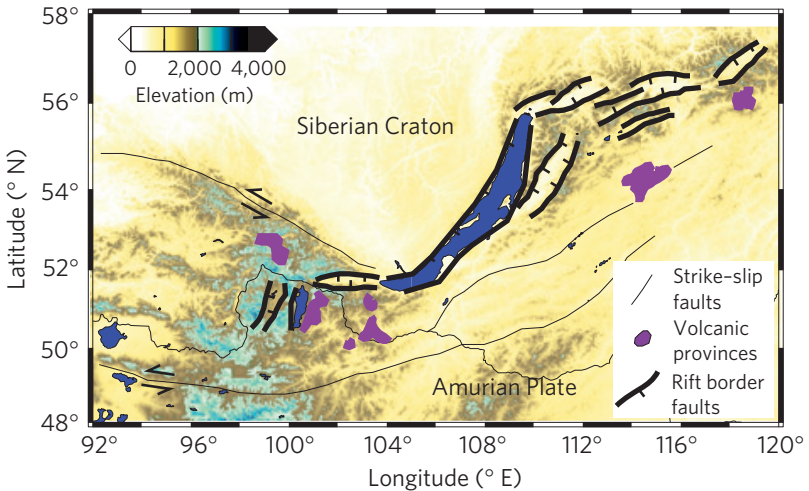

c

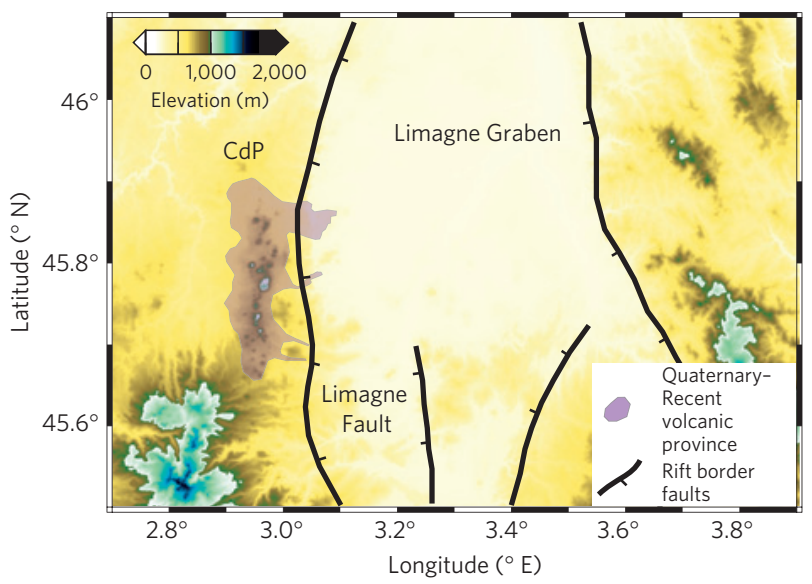

Figure 1 | Examples of off-rift volcanism. a-c, Topographic, structural and volcanic architecture of the MER (a), Baikal Rift (b) and Chaine des Puys $(\mathrm{CdP})(\mathbf{c})$. For the MER, Miocene border faults are thick black lines, with the direction of downthrow indicated. The Quaternary-Recent faults within the rift are thin black lines. Early syn-rift volcanic edifices are purple, and Quaternary-Recent volcanoes and cones are red. Note that the early syn-rift volcanism ranges from being just outboard of the Miocene border faults to as far as $100 \mathrm{~km}$ from the rift valley. For the Baikal Rift and CdP major rift, normal faults are thick black lines and the spatial extent of volcanism is shown in purple.

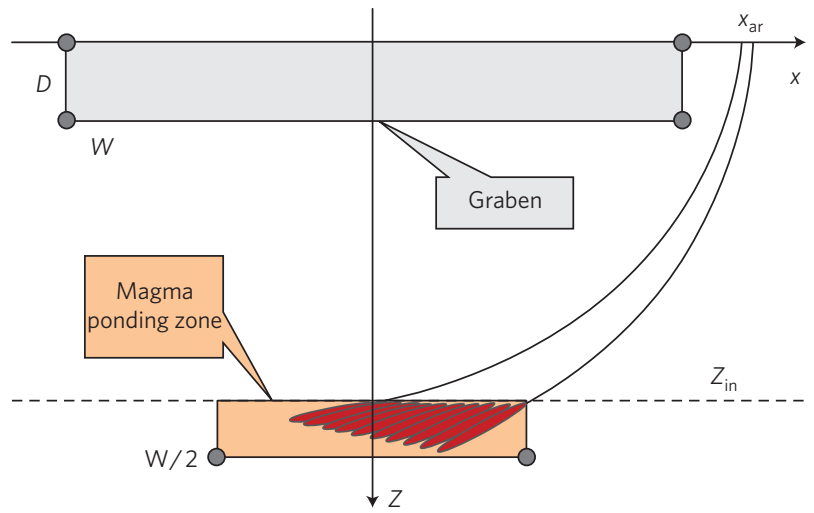

Figure 2 | Set-up for the numerical experiments. In each model, ten equally spaced dykes are released at $z_{\text {in }}$ from half of a ponding zone as wide as the half-width of the graben. One simulation corresponds to a run of each individual dyke. All the parameters employed in the numerical runs are listed in Supplementary Table 1 and Supplementary Methods.

respectively (Methods and Fig. 3c). This volume constitutes a stress barrier zone that deflects the ascending dykes to the rift sides. Sideways from the rift centre, $\sigma_{3}$ becomes first inward dipping and then horizontal (Fig. 3). A similar pattern for $\sigma_{3}$, on a smaller scale, was obtained by modelling the unloading due to ice-cap retreat at Kverkfjöll volcano, Iceland ${ }^{16}$.

Depending on where the dykes nucleate relative to the stress barrier zone, three scenarios for their propagation and for the final surface distribution of magmatism occur.

When $z_{\text {in }}<z_{1}$ in-rift volcanism occurs. Magma-filled dykes ascend subvertically, or propagate laterally within the rift parallel to the axis (Fig. 3a). The dyke arrivals are spread within the graben (vertical bars in Fig. 4a for $x^{*}<1$ ). For deep grabens $z_{1}$ is shallow ( $D \sim 1 \mathrm{~km}$ and $W \sim 100 \mathrm{~km}$ gives $z_{1} \sim 10 \mathrm{~km}$ ) so that in-rift arrivals occur for only shallow nucleation depths. For a nucleation depth of $40 \mathrm{~km}$, in-rift volcanism occurs for only wide $(>100 \mathrm{~km})$ and shallow $(<0.6 \mathrm{~km})$ rift depressions, for which the ponding zone is above the stress barrier, or the graben depth is too small to create one (in-rift volcanism area in Fig. 4b). Shallower nucleation depths result in enlarging the in-rift volcanism area (Fig. 4c), as expected for the North Volcanic Zone of Iceland (NVZ) and for Quaternary volcanism in the MER.

When $z_{1}<z_{\text {in }}<z_{2}$, our model predicts off-rift volcanism with sill formation. The injected magma forms subhorizontal magmatic sheets that, depending on their initial distance from the rift axis, get trapped as stacked sills above the ponding zone or escape to the side of the stress barrier, turning into subvertical dykes and eventually reaching the surface (Fig. 3b). The dyke arrival distance as a function of $z_{\text {in }}$ scales with the rift width (Fig. 4a). For a given set of parameters, dykes emerge very tightly spaced at a distance from the rift axis equal to about 1-2 (and up to 3 ) graben half-widths (Fig. $4 \mathrm{a}, x^{*}>1$ ). This may result in the construction of large off-rift volcanoes aligned parallel to the rift. As the rift matures, the magma ponding zone near the base of the crust becomes progressively shallower due to crustal thinning and to sills piling one above the other and functioning as new, shallower reservoirs, driving the system towards the condition of case 1 and to a transition to in-rift volcanism (Fig. 4c).

When $z_{\text {in }}>z_{2}$, off-rift volcanism occurs without sill formation: vertical dykes are deflected towards the rift sides, with a more scattered arrival distribution at the surface (Fig. 3c). $z_{2}$ being relatively deep, this occurs with deep nucleation depths below shallow and narrow grabens, as illustrated by the three points in the dashed rectangle in Fig. $4 \mathrm{a}$ and the case $W=25 \mathrm{~km}, D=0.4 \mathrm{~km}$ in Fig. $4 b$. 

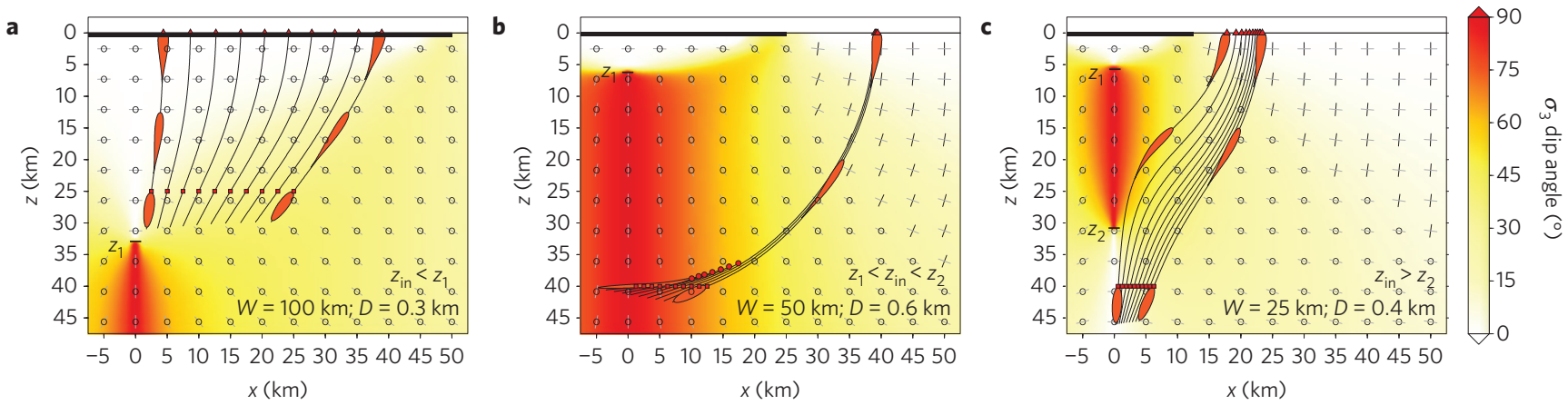

Figure $\mathbf{3}$ | Numerical simulations. a-c, Dyke trajectories for $z_{\text {in }}$ above (a), within (b) and below (c) the stress barrier zone. Red squares indicate the upper tip of the dyke at injection, red circles indicate that a dyke has been arrested as sill, red triangles indicate the position of the arrival at the surface. Black and grey segments show the directions of $\sigma_{1}$ and $\sigma_{3}$ respectively (a circle indicates direction perpendicular to the page) for three nominal sets of graben width, $W$ and depth, $D$, (see insets). The dip angle of $\sigma_{3}$ is colour-shaded: where subvertical (reddish colour), a stress barrier to vertical ascent of dykes is acting. The stress barrier is expected to dissipate in a weak lower crust or mantle.
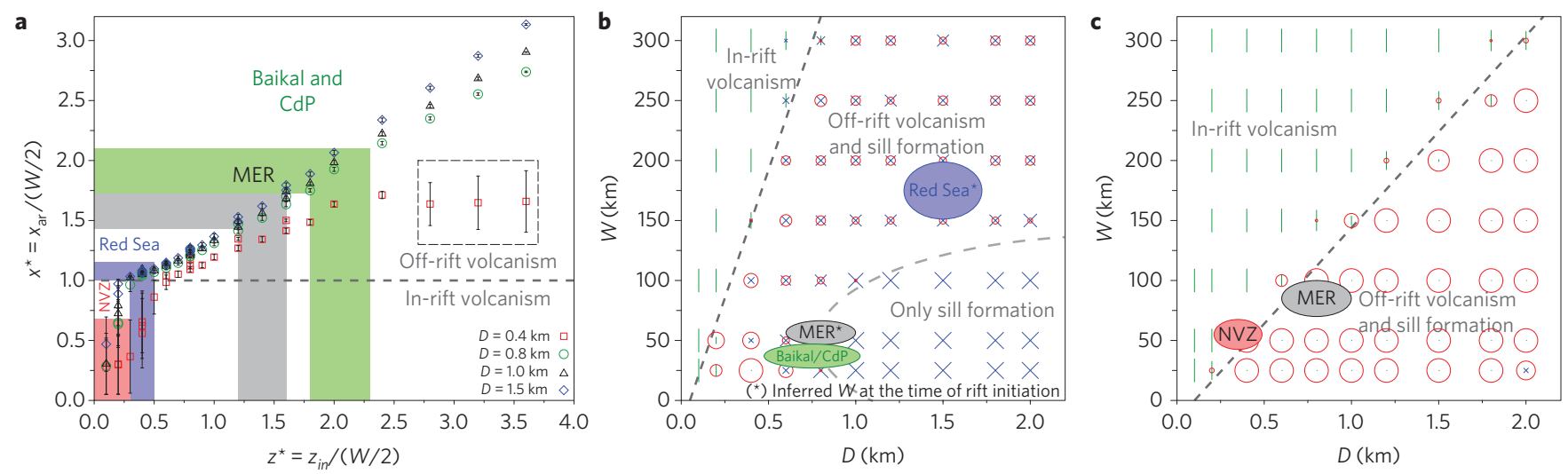

Figure 4 | Summary of the numerical results. a, Normalized arrival distance $x^{*}=x_{a r} /(W / 2)$ from the rift axis as a function of the normalized injection depth $z^{*}=z_{\text {in }} /(W / 2)$. The vertical bars indicate the spatial spreading of dyke arrivals at the surface. The vertical shaded areas locate on the diagram four rift systems. The dashed rectangle highlights three points for which $z_{\text {in }}<z_{2}$. $\mathbf{b}$, Results for $z_{\text {in }}=40 \mathrm{~km}$. The size of the symbols $(\mathrm{I}, \mathrm{O}$ and $\mathrm{X}$ ) is proportional to the number of dykes that end up in-, off-rift or as sills, respectively. $\mathbf{c}$, Same as $\mathbf{b}$, with $z_{\text {in }}=20 \mathrm{~km}$.

The stress barrier is maintained only in the elastic layer. Observations of deep seismicity in young rifts suggest a strong midlower crust ${ }^{17-19}$ that maintains the stresses necessary to create a stress barrier at any crustal depth. If the lower crust and upper mantle are weak, the elastic stresses dissipate and $z_{2}$ may coincide with the bottom of the elastic layer.

For a given nucleation depth, the aspect ratio of the rift depression determines in-rift or off-rift dyke propagation. Shallow and wide rift depressions favour in-rift dyke arrivals, whereas narrow and deep depressions favour off-rift arrivals, coupled or not with sill intrusions at depth (Fig. 4b). The relative proportion of extruded to intruded magma decreases for deep and narrow grabens, approaching non-volcanic rifts (Fig. 4b, only sill formation area). In general, this also depends strongly on model parameters such as magma buoyancy, initial volume of the magma batches (controlling the dyke driving pressure) and crustal fracture toughness. For example, the only sill formation area of Fig. $4 \mathrm{~b}$ disappears if magma buoyancy is increased by $15 \%$ (Supplementary Table 1 and Supplementary Material), or if the initial volume is doubled. Also, the scarcity of sills in Fig. $4 \mathrm{c}$ is due to a higher magma buoyancy linked to a lower initial confining pressure. The dyke driving pressure does not impact significantly on the dyke arrival distance from rift axis, $x_{\mathrm{ar}}$, as with our parameters the unloading stresses dominate over dyke driving pressure.

Our model is consistent with observations from major rift systems. For parameters appropriate for the MER, CdP and Baikal rifts, we expect sill stacking and off-rift volcanism. Indeed, in these cases the lower crust is heavily intruded with sills ${ }^{20,21}$ and off-rift volcanism has accompanied early rifting ${ }^{5,7}$ (see Fig. 1 and Supplementary Table 2 for numerical values of $W$ and $D$ ). At the MER, the off-rift volcanic rocks have experienced fractional crystallization pressure higher than the volcanism found along the rift axis, suggesting that magma feeding off-rift volcanoes stalls at greater crustal depths than it does for those in the rift axis, probably because of their more complex pathway. However, both magmas originate from the same parental source of basalts formed from decompressional melting of the upper asthenosphere beneath the rift $^{22,23}$. The basalts exhibit differences in major and trace elements, and radiogenic isotopes that vary more over the distances of adjacent scoria cones than between the axial and flank volcanic fields ${ }^{24}$.

Notably, as the crust thins and sills progressively stack, causing the shallowing of the injection depth, eventually up to $z=z_{1}$, where $\sigma_{3}$ turns horizontal, the magma pathways and volcanism become confined to the rift centre. In more evolved rifts where protracted intrusion has significantly heated the plate, such as in Afar, $<10-\mathrm{km}$-deep magma reservoirs beneath axial volcanoes are common $^{25,26}$ and feed episodic dykes along the axis ${ }^{4,27}$.

Our model is also consistent with observations of subvertical dykes feeding off-rift volcanism and $\sim 20-25$-Myr-old basaltic dyke swarms along the Red Sea Rift margin ${ }^{28}$, which are thought to accommodate strain after the onset of rifting $29-31 \mathrm{Myr} \mathrm{ago}^{\mathrm{I1}, 29}$. In contrast, rifts with mild topographic expression (wide and shallow 
depression), such as the NVZ, lack significant off-rift volcanism. This is predicted by our model, as the very shallow injection depth, which is above the expected stress barrier zone, creates a wide dyke swarm area within the rift (Fig. 3a).

Earlier models considered flexure of the lithosphere and interaction of magma with large boundary faults to explain rift flank volcanism ${ }^{5}$. Boundary faults certainly influence the ascent of magma in the upper crust. However, our models suggest that if unloading stresses are ignored, dykes from a ponding zone beneath the rift ascending in a stress field associated with normal faults always reach the surface within the graben (Supplementary Fig. 1). The flexural behaviour of the crust may add local variations in the stress pattern, not expected to alter the overall distribution of stresses ${ }^{5}$; furthermore, the flexural response to rifting creates topography highs at the rift shoulders, attracting dykes and reinforcing off-rift magmatism ${ }^{15,30}$.

Our model may shed light on the history of tectonically complicated areas, such as the Upper Rhine Graben and other fossil continental rifts in which the existence or non-existence of surface volcanism has remained unexplained.

\section{Methods}

Considering a plane $(x, z)$, perpendicular to the rift and with origin at the rift centre (Fig. 2) we express the condition for which $\sigma_{3}$ is vertical along the $z$ axis (vertical, downward directed) by requiring that:

$$
\sigma_{z z}(x=0, z)>\sigma_{x x}(x=0, z)+\sigma_{\text {tec }}
$$

being the unloading shear stresses null in $x=0$. By calculating $\sigma_{z z}$ and $\sigma_{x x}$ from the formulas for the unloading ${ }^{14,30}$, we find that the stress barrier is located at depth:

$$
\frac{W}{2} \cdot \frac{1-\sqrt{1-K^{2}}}{K}<z<\frac{W}{2} \cdot \frac{1+\sqrt{1-K^{2}}}{K} \quad \text { if } K=\frac{\pi}{2} \cdot \frac{\sigma_{\text {tec }}}{P_{0}}<1
$$

If $K>1$ (equivalent to $D<\pi \sigma_{\text {tec }} /(2 \rho g)$ ), equation (1) does not hold for any $z$ and vertical dyke propagation will always be favoured. $\sigma_{1}$ is always perpendicular to the page in $x=0$ in our plain strain approximation model $\left(\sigma_{y y}=v\left(\sigma_{x x}+\sigma_{z z}\right)\right.$, with $v$ Poisson's number).

Equation (2) can be non-dimensionalized by using $z *=z /(W / 2)$ :

$$
\frac{1-\sqrt{1-K^{2}}}{K}<z^{*}<\frac{1+\sqrt{1-K^{2}}}{K}
$$

The non-dimensional centre of the stress barrier is $c^{*}=K^{-1}$ and its extension is $e^{*}=(2 / K)(1-K)^{1 / 2}$.

\section{Received 2 May 2013; accepted 6 February 2014;} published online 23 March 2014

\section{References}

1. Lubimova, E. A. Heat flow patterns from Baikal and other rift zones. Tectonophysics 8, 457-467 (1969).

2. Bown, J. W. \& White, R. S. Effect of finite extension rate on melt generation at rifted continental margins. J. Geophys. Res. 100, 18011-18029 (1995).

3. Ebinger, C. J. \& Casey, M. Continental breakup in magmatic provinces: An Ethiopian example. Geology 29, 527-530 (2001).

4. Wright, T. J. et al. Magma maintained rift segmentation at continental rupture in the 2005 Afar dyking episode. Nature 442, 291-294 (2006).

5. Ellis, M. \& King, G. Structural control of flank volcanism in continental rifts. Science 254, 839-842 (1991).

6. Morton, W. H., Mitchell, J. G., Rex, D. C. \& Mohr, P. Riftward younging of volcanic units in the Addis-Ababa region, Ethiopian rift valley. Nature 280, 284-288 (1979)

7. Kiselev, A. I. Volcanism of the Baikal rift zone. Tectonophysics 143, 235-244 (1987).

8. Richet, P. Guide des Volcans de France (BRGM Belin, 2003)

9. Abebe, T., Mazzarini, F., Innocenti, F. \& Manetti, P. The Yerer-Tullu Wellel volcanotectonic lineament: A transitional structure in central Ethiopia and the associated magmatic activity. J. Afr. Earth Sci. 26, 135-150 (1998).
10. Chernet, T., Hart, W. K., Aronson, J. L. \& Walter, R. C. New age constraints on the timing of volcanism and tectonism in the northern Main Ethiopian Rift southern Afar transition zone (Ethiopia). J. Volcanol. Geotherm. Res. 80, 267-280 (1998)

11. Bosworth, W., Huchon, P. \& McClay, K. The Red Sea and Gulf of Aden basins. J. Afr. Earth Sci. 43, 334-378 (2005).

12. McKenzie, D. Some remarks on the development of sedimentary basins. Earth Planet. Sci. Lett. 40, 25-32 (1978).

13. Bosworth, W. Off-axis volcanism in the Gregory Rift, east Africa: Implications for models of continental rifting. Geology 15, 397-400 (1987).

14. Davis, R. \& Selvadurai, A. Elasticity and Geomechanics (Cambridge Univ. Press, 1996).

15. Maccaferri, F., Bonafede, M. \& Rivalta, E. A quantitative study of the mechanisms governing dike propagation, dike arrest and sill formation. J. Volcanol. Geotherm. Res. 208, 39-50 (2011).

16. Hooper, A. et al. Increased capture of magma in the crust promoted by ice-cap retreat in Iceland. Nature Geosci. 4, 783-786 (2011)

17. Deverchere, J. et al. Depth distribution of earthquakes in the Baikal Rift system and its implications for the rheology of the lithosphere. Geophys. J. Int. 146, 714-730 (2001)

18. Foster, A. N. \& Jackson, C. A. Source parameters of large African earthquakes: Implications for crustal rheology and regional kinematics. Geophys. J. Int. 134, 422-448 (1998)

19. Craig, T. J., Jackson, C. A., Preistley, K. \& McKenzie, D. Earthquake distribution patterns in Africa: Their relationship to variations in lithospheric and geological structure, and their rheological implications. Geophys. J. Int. 185, 403-434 (2011).

20. Thybo, H. \& Nielsen, C. A. Magma-compensated crustal thinning in continental rift zones. Nature 457, 873-876 (2009).

21. Mackenzie, G. D., Thybo, H. \& Maguire, P. K. H. Crustal velocity structure across the Main Ethiopian Rift: Results from 2-dimensional wide-angle seismic modeling. Geophys. J. Int. 162, 994-1006 (2005).

22. Peccerillo, A. et al. Petrogenesis of silicic peralkaline rocks in the Ethiopian Rift: Geochemical evidence and volcanological implications. J. Afr. Earth Sci. 48, 161-173 (2007).

23. Rooney, T. O., Furman, T., Bastow, I., Ayalew, D. \& Yirgu, G. Lithospheric modification during crustal extension in the Main Ethiopian Rift. J. Geophys. Res. 112, B10201 (2007).

24. Rooney, T. O., Bastow, I. D. \& Keir, D. Insights into extensional processes during magma assisted rifting: Evidence from alligned scoria cones. J. Volcanol. Geotherm. Res. 201, 83-96 (2011).

25. Pagli, C. et al. Shallow axial magma chamber at the slow-spreading Erta Ale Ridge. Nature Geosci. 5, 284-288 (2012).

26. Nobile, A. et al. Dike-fault interaction during the 2004 Dallol intrusion at the northern edge of the Erta Ale Ridge (Afar, Ethiopia). Geophys. Res. Lett. 39, L19305 (2012)

27. Grandin, R. et al. Seismicity during lateral dike propagation: Insights from new data in the recent Manda Hararo-Dabbahu rifting episode (Afar, Ethiopia). Geochem. Geophys. Geosyst. 12, Q0AB08 (2011).

28. Pallister, J. S. et al. Broad accommodation of rift-related extension recorded by dyke intrusion in Saudi Arabia. Nature Geosci. 3, 703-710 (2010).

29. Wolfenden, E., Ebinger, C. J., Yirgu, G., Renne, P. \& Kelley, S. P. Evolution of a volcanic rifted margin: Southern Red Sea, Ethiopia. Geol. Soc. Am. Bull. 117, 846-864 (2005)

30. Dahm, T. Numerical simulations of the propagation path and the arrest of fluid-filled fractures in the Earth. Geophys. J. Int. 141, 623-638 (2000).

\section{Acknowledgements}

C. Pagli is acknowledged for extracting the SRTM DEM for the CdPs. The work was financially supported by the ERC StG project N. 240583 CCMP-POMPEI. V.A. acknowledges the PRIN 2009 project.

\section{Author contributions}

F.M. and E.R. planned the paper, the numerical experiments and formulated the analytical modelling. F.M. implemented and ran the BE code. D.K. and V.A. compared the numerical results with natural cases. D.K. made Fig. 1 with input from V.A. F.M. made Figs 2-4 with input from E.R. All authors discussed the results and contributed to writing the manuscript.

\section{Additional information}

Supplementary information is available in the online version of the paper. Reprints and permissions information is available online at www.nature.com/reprints. Correspondence and requests for materials should be addressed to F.M.

\section{Competing financial interests}

The authors declare no competing financial interests. 